\title{
INTEGRATED LOGISTICS SUPPORT IN HIGH-TECHNOLOGY COMPLEX SYSTEMS THAT ARE USED BEYOND THEIR DESIGNED LIFE
}

\author{
K.R. Lambert ${ }^{1 *}$
}

\section{ARTICLE INFO}

\begin{tabular}{l}
$\begin{array}{l}\text { Article details } \\
\text { Submitted by authors } \\
\begin{array}{l}\text { Accepted for publication } \\
\text { Available online }\end{array} \\
\text { 8 Sep } 2017 \\
14 \text { Dec } 2020\end{array}$ \\
\hline $\begin{array}{l}\text { Contact details } \\
\text { Corresponding author } \\
\quad \text { keith.lambert101@yahoo.com }\end{array}$ \\
$\begin{array}{l}\text { Author affiliations } \\
1 \quad \text { KeNa Logistics }\end{array}$ \\
\hline $\begin{array}{l}\text { ORCID@ identifier } \\
\text { K.R. Lambert } \\
\text { https://orcid.org/0000-0003-4080-0910 }\end{array}$
\end{tabular}

DOI

http://dx.doi.org/10.7166/31-4-1828
ABSTRACT

A high-technology complex system can be supported during its extended life by using an integrated logistics support system (ILSS). The process to develop an ILSS is used and is familiar in industrial and military complex systems. This paper discusses the advantages and implications of developing an ILSS for high-technology complex systems that are being used beyond their intended designed life. A literature review of the integrated logistics support (ILS), obsolescence, and diminishing manufacturer sources and material shortages (DMSMS) literature was conducted. The ILS and obsolescence components of several hightechnology complex systems were studied for this paper.

\section{OPSOMMING}

'n Hoë-vlak, tegnologies komplekse stelsel kan onderhou word gedurende 'n verlengde lewensiklus deur gebruik te maak van 'n geïntegreerde logistieke ondersteuningstelsel. So 'n stelsel is bekend in die industrie en in militêre stelsels. Hierdie artikel bespreek die voordele en implikasies verbonde aan die ontwikkeling van so 'n stelsel vir 'n hoë-vlak, tegnologies komplekse stelsel wat in gebruik bly na die oorspronklike ontwerpleeftyd verstryk. ' $n$ Literatuurstudie van die geïntegreerde logistieke ondersteuning, veroudering, en verminderende vervaardiger hulpbronne en materiaal tekorte is uitgevoer. Die geïntegreerde logistieke ondersteuning en verouderingskomponente van verskeie hoë-vlak, tegnologies komplekse stelsels is ondersoek.

\section{INTRODUCTION}

Logistics influences the global economy and organisations in two ways. First, a firm incurs many expenses, one of these being logistics costs. Economic decisions are affected by these expenses and by logistics costs, and vice versa. Second, logistics facilitates the sale of goods and services and the associated customer service, including various economic transactions. The main focus of many firms is customer service [1], and the competitive advantage of many companies can be improved using logistics.

By implementing an integrated logistics support plan (ILSP), successful integrated logistics support (ILS) can be performed. During the concept phase of system procurement, this ILSP is developed and updated throughout a system's life cycle [2], and will guide management through the various life cycle stages. Successfully implementing an ILSS provides the following:

1) A system that is more effective, and is used by the customer during the system's life-span.

2) A system that conforms to the operational and user requirement statements during the system's lifecycle.

3) A business that runs more efficiently, ensuring that budgets are met, with realistic forecasting, measuring of actual expenditure, and no surprises.

4) No crisis upgrades, modifications, or costly repairs owing to premature activities.

5) No costly failures in critical, expensive, and long lead-time items. 


\subsection{Logistics}

Logistics is recorded as having originated in the military during wars as early as 490 and $481 \mathrm{BC}$ [3]. Thus "logistics, which includes the integration of many activities and elements, has become significant in each phase of the system/product life-cycle" [4]. In this context, "logistics support is viewed as the composite of all considerations necessary to assure the effective and economical support of a system throughout its programmed life-cycle. It is an integral part of all aspects of system planning, design and development, test and evaluation, production and/or construction, consumer use, and system retirement. The elements of logistics support must be developed on an integrated basis with all other segments of the system" [4].

Complexity in a military environment is illustrated by an example from the First Gulf War. Pagonis [5] states that, between August 1990 and August 1991, 1.3 billion gallons of fuel were pumped; more than 122 million meals were planned, moved and served; 31,800 tons of mail were handled; and 52 million miles were driven. "Running logistics for the Gulf War has been compared to transporting the entire population of Alaska, along with their personal belongings, to the other side of the world, on short notice" [6]. Support services include, but are not limited to, social counsellors, ammunition, carpenters, planes, morticians, tanks, bakers, cashiers, and bureaucrats.

\subsection{Integrated logistics support system (ILSS)}

The discipline of integrated logistics has evolved over time, and has been influenced by the technological capacity of system requirements and the complex environment in which these systems operate. Technological advances in capacity are evident in data storage, communication, and information technology (IT). In an engineering environment, the amount of documentation that is produced would fill truckloads if printed out. Fortunately, in our technologically advanced era, these documents can all be stored on electronic media.

Even though the ILSS originated in the military, it is currently also being used in industry. Applications include civilian radar, satellite earth stations, and navigational aids. An ILSS was also used in the National Aeronautics and Space Administration (NASA) space shuttles. One such application in South Africa was the modular nuclear reactor design (now a defunct project). Jones [2] mentions that ILSS is no longer applicable just to the military, but is used in industry as well; and he offers the examples of commercial aviation, rail systems, and the petroleum industry. System maintenance depends on the system being used and the environment in which it is used. In South Africa, the ILS of military systems is typically performed by a outsourced private contractor who undertakes depot-level maintenance on the system [7].

\subsection{ILS literature}

Various authors provide different definitions for logistics and ILS, which makes the study and implementation of ILSS a demanding task. These authors come from different eras of the 20th century and from varying disciplines, ranging from the military to industry and to engineering. These discrepancies tend to cause misinterpretations and misunderstandings of ILS and logistics. The literature studied included military, management, and engineering sources. Key definitions of ILS from engineering, industry, the military, and other sources and various authors are provided below.

\subsubsection{Engineering}

Blanchard [4], in his book Logistics engineering and management, considers the ILS of a system from an engineering and management perspective, as well as support throughout the system's life-cycle. He defines integrated logistics support as follows:

A management function that provides the initial planning, funding, and controls which help to assure that the ultimate consumer (or user) will receive a system that will not only meet performance requirements, but one that can be expeditiously and economically supported throughout its programmed life-cycle. A major ILS objective is to assure the integration of the various elements of support, i.e., test and support equipment, spare/repair parts, etc. [4]

\subsubsection{Industry}

There are various industrial definitions of integrated logistics support, including those by Hutchinson [8], Quayle [9], Jones [2], Lambert and Stock [10] (cited in Juga [11]), and Adler [12] (cited in Juga [11]). 
Although Jones views ILS as a technical discipline for military forces, he also discusses the ILS of industrial systems such as shipping, rail systems, the petroleum industry, and commercial aviation. He regards ILS in a non-military environment as providing customer services or product support. Jones' definition of ILS follows:

Integrated Logistics Support (ILS) is the disciplined and unified management of the technical logistics disciplines that plan and develop support for military forces. In general this means that ILS is the management organization that plans and directs the activities of many technical disciplines associated with the identification and development of logistics support requirements for military systems. There are comparable organizations outside the military, which provide the same capabilities. In a commercial company this organization may be called product support, customer services, or many other similar names. [2]

In a later edition of his book, Jones [13] defines ILS as follows:

Integrated Logistics Support (ILS) is the disciplined and unified management of all activities necessary to produce a supportable system design and a reasonable support capability to achieve a predetermined set of measurable objectives within an acceptable cost of ownership. [13]

\subsubsection{Military}

Various military sources were consulted for the definition of ILS: US MIL-STD-1368-A [14], US Army Regulation 700-127 [15], and the Department of Defense Directive (DoDD) [16]. The definition from MILSTD-1368-A [14] is used in this paper, and reads as follows:

The disciplined, unified, and iterative approach to the management and technical activities necessary to:

- Integrate support considerations into system and equipment design;

- $\quad$ Develop support requirements that are related consistently to readiness objectives, to design, and to each other;

- $\quad$ Acquire support; and

- $\quad$ Provide the required support during the operational phase at minimum cost.

\subsubsection{Proposed definition}

Based on the various available definitions, Marshall and Lambert [17:554] have developed a definition of ILS in the context of a high-technology system in a developing country:

A management responsibility which ensures that the most appropriate, reliable product/s and/or technical service/s supplied are of the highest quality and are both efficient and effective, are of the correct quantity, at the correct location, at the correct time to support a system throughout its intended or extended life-cycle at the minimum cost.

\section{TRADITIONAL ILS}

\subsection{ILS sub-elements}

Integrated logistics support consists of various sub-elements. These are defined by diverse sources including, but not limited to: Army Regulation 700-127 [15], Blanchard [4], Carpenter [18], Finkelstein and Guertin [19], Jones [2], Langford [20], and MIL-STD-1368-A [14]. From these sources a list of sub-elements has been identified, and is shown in Table 1 .

A maintenance concept and maintenance philosophy is required for a system, to define the responsibilities and roles for maintenance. Maintenance performance may be measured by, but is not limited to: mean time between failure (MTBF), mean time to repair (MTTR), and availability.

Data and documentation are also required for the support and repair of the system in the form of operator or technical manuals and operational software. Support and test equipment is required in order to set up the system and to measure, test and detect failures. Specific facilities are needed for training and to house the system. Transportation is needed to transport moveable assemblies and sub-assemblies, and to move spare parts from one place to another. This calls for specified storage requirements, specialised handling requirements, and special packaging to minimise damage. For the manpower and personnel element, staff who have the 


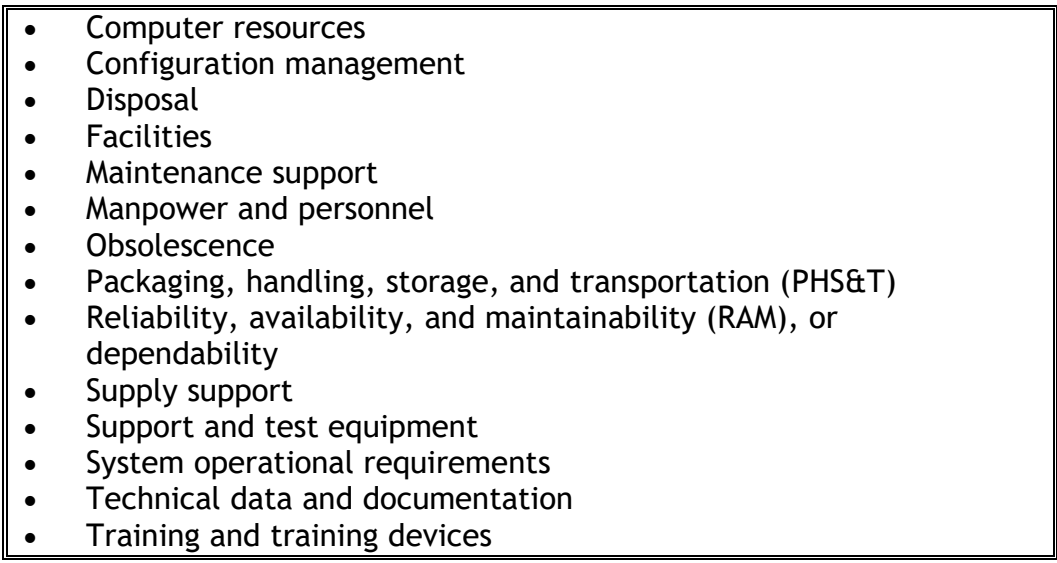

necessary skills, competencies, and qualifications are required. Sufficient training devices are needed to train the personnel - including specific detailed training requirements and a training needs analysis.

Reliability, availability, and maintainability, otherwise known as RAM, are necessary to determine the following: the required performance characteristics, failure rate, reliability, availability, and maintainability of a system. Availability requirements are essential to be able to plan for maintenance. Maintainability is needed in order to determine whether an item should be repaired or discarded. The computer resources element is necessary in the form of firmware, software, and hardware to support the system - including the operation and support of the support and test equipment. Configuration management identifies the characteristics of parts, as they sometimes have to be replaced by improved technology. Configuration control is thus a necessity, requiring periodic audits.

Disposal of a system (or of a component) occurs when the system (or component) is no longer required, or has become obsolete. Obsolescence may be said to occur when the system or component is no longer available, or is no longer supported by the original equipment manufacturer (OEM). Disposal might occur by selling the entire system, or parts of it, to another user.

\subsection{Obsolescence}

High-technology complex systems can suffer from component obsolescence, and might need further modification, refurbishment, or redesign. Understanding and defining obsolescence is important here. Diminishing manufacturer sources and material shortages (DMSMS) are regarded as obsolescence. DMSMS is defined thus [21]: “...the loss or impending loss of manufacturers or suppliers of critical items and raw materials due to discontinuance of production”.

Obsolescence occurs when spare and repair parts are no longer available. This might be simply because the manufacturer no longer makes the component or has gone out of business. Some manufacturers even design for obsolescence by introducing new products into the market before the previous product has reached maturity. The primary reasons for obsolescence are technological changes and changing market trends [22]. According to Sandborn [23] "due to the length of the system's manufacturing and planned support life, and unforeseen life extensions to support the system longer than its planned end of support date, the parts and other resources necessary to support the system become unavailable before the system's demand for them ends".

Electronic components are not alone in being susceptible to obsolescence, since mechanical components can also become obsolete [24]. The life cycles of defence systems are lengthening as newer technology becomes available, replacing obsolete components, while governments are decreasing their military budgets.

Most equipment suffers from obsolescence throughout its intended and often extended life cycle. This affects software, standards, support and test equipment, and logistics products and processes [25]. The 
risk of an obsolete component, as determined by severity and probability, will vary from one environment to another and from one system to another, as some components are critical to the functionality of the system as a whole. The loss of skills and knowledge will also affect an organisation. Staff turnover - and so the loss of skills, and particularly of scarce critical skills - can severely affect an organisation.

An example of attitudes to dealing with obsolescence is contained in a document from Sherwin [27], in which he describes how toasters are repaired in Kenya but discarded in the United States of America (USA). The toasters in Kenya are less expensive to purchase, more robust, technologically simpler, and easier to repair than toasters in the USA.

High-technology complex systems take many years (from five to ten years, if not longer) of research and development. These complex systems have long (typically between 20 and 40 years, sometimes even longer) life cycles. Further supportability issues are evident in the lengthy development and implementation phases of systems, especially when these systems consist of multiple systems/fleets. An example would be when electronic components that were identified in the design phase might still be available during the manufacturing phase of the first system, but might be obsolete by the time the last system in a fleet is manufactured.

High-technology complex systems that suffer from obsolescence and that are used beyond their designed life-cycle are often refurbished or upgraded to extend their life. Should the ILSS not be upgraded or revised when the system is upgraded, this will result in reduced performance and cost-effectiveness, as the original ILSS will be outdated and unusable.

Management and planning to mitigate the risk of obsolescence has been a reactive process in most organisations. This mind-set needs to change to one of the pro-active management of obsolescence and DMSMS [28], to ensure competitive advantage and sustainable performance.

\section{IN REALITY}

In order to support and maintain a high-technology complex system throughout its intended and extended life cycle, an ILSS needs to be implemented, and subsequently revised and updated, if the system itself is upgraded. By successfully implementing an ILSS, the overall objectives and intent of the complex system can be sustainably achieved. However, certain assumptions are necessary:

1) The ILSS is updated when the system is upgraded.

2) System integration is carried out when an upgrade or change takes place within the system.

3) The technology, skills, and knowledge needed for support are readily available.

4) The high-technology complex system is used according to the original design specifications.

5) Support systems from the OEM are available.

\subsection{Obsolescence in reality}

Several high-technology complex systems were studied for this paper, including radar, satellite earth station and navigational and guidance systems (all in operational phase), and a modular nuclear reactor (which was then in the design phase, but has since been shelved by government). Discussions and interviews with industry specialists who are subject-matter experts in radio telescopes and aviation confirmed the results of the case analysis.

\subsection{Age}

Most of the high-technology complex systems considered in this study are being used beyond their intended life, and suffer from obsolescence and aging. Some of the legacy systems in the South African and South American contexts are over 35 years old. Specially trained staff and specialised support and test equipment (S\&TE) are needed when these systems are upgraded and the system's life cycle is extended.

One of the high-technology complex systems investigated in this study consists of 10 systems, is more than 35 years old, and has a high incidence of failure associated with it. Some of the sub-systems come from different technological eras and from different developers/designers and suppliers. This specific system has had several upgrades, and is being used beyond its intended designed life. It is nevertheless expected that the system will be used for years to come. 


\subsection{Obsolescence and supportability}

A high-technology complex system is not necessarily supported for its entire life by the OEM. The latter might find it more profitable to offer other services and products, or consider that the frequently extended life of the system exceeds the OEM's original design considerations. In some cases an OEM is acquired by another company, or goes out of business. International OEMs might not have an office or a representative in a particular country - in this instance, South Africa. If they did have one in the past, it might not have been possible to maintain a South African office. Sourcing and procuring components becomes difficult when this is the case, and could induce premature obsolescence and reduce sustainable supportability.

DMSMS and obsolescence might occur when information notices and updates are not sent out by suppliers, or the end-user of the equipment does not receive them. This is more likely to occur if the end-user is in a developing country and an international supplier is involved. Long lead times are the norm, even if the OEM is willing to support the older equipment, as the component might not necessarily be commercially 'off the shelf' (COTS) and might need to be specifically made. To increase the supportability of a system, alternative repair practices are often developed, or a re-engineering or re-design of elements is needed.

\subsection{Usage patterns and system operating environment}

The existing usage pattern of the system might be different from the original specified and design environment. The operating environment might include extreme and harsh environmental conditions, such as humidity, incorrect temperatures, dust levels, or sea spray. Some systems, such as the radio navigational aids used on runways, might operate outside an environmentally controlled building. Transportable systems might be moved over some rough terrain, inducing vibration in the equipment. These high-technology systems are robust, but only up to a certain level. These factors will have an impact on obsolescence and the usability of the system.

\subsection{Summary of 'In reality'}

This section has discussed the impact on obsolescence and supportability in the context of a developing country. The assumptions mentioned above need to be tailored to the development of an appropriate ILSS:

1) Many complex high-technology systems are used beyond their intended life cycle, and suffer from obsolescence and system aging.

2) Specially trained personnel and specialised support and test equipment are needed to support the old legacy systems, ensuring that they achieve their intended operational objectives.

3) The beyond-design-capacity and high utilisation rates of expensive and difficult-to-obtain assets are common (known as 'sweating the assets').

4) Ad hoc replacement/repair decisions and capacity overload in the long term (a 'taxi-mentality', based on the use of minibus taxis in Africa)

There is a significant difference between the underlying assumptions and the reality within which some systems operate in a developing country. The identified ILS elements recorded in Table 1 have been elaborated on, and are presented in Table 2.

Table 2: Constraints of a developing country with regard to ILS elements (Source: [7])

- $\quad$ Computer resources and systems: these also become obsolete owing to technological advances.

- $\quad$ Configuration management: all system items need to be under configuration control. One of the systems examined in South Africa does not adhere to configuration management principles, and manual amendments are not controlled.

- Disposal: system disposal takes place later in the system's life. Some systems are cannibalised, some are mothballed, and some are sold.

- $\quad$ Facilities: sometimes a system must use the facilities that are available, as they are expensive to build and maintain.

- Maintenance support: in some instances, maintenance support is lacking, or is not planned or properly implemented, resulting in maintenance personnel-induced errors.

- Manpower and personnel: concerns the competency and skill level of personnel in order to perform the job, particularly given the skills shortage and different technology used in the systems. 
- Obsolescence: this element needs to be managed proactively and not reactively, as in some systems this causes delays in the system becoming re-operational.

- $\quad$ Packaging, handling, storage, and transportation (PHS\&T): assemblies and subassemblies being sent from one country to another for repair are not handled, packaged, packed, marked, or preserved properly, resulting in further failures and damage. The OEM specifications are not always followed with regard to storage. Adequate transport in some developing countries can be very challenging to provide at times.

- Reliability, availability, and maintainability (RAM), or dependability: the system needs to be available when needed and reliable and maintainable in the modes of operation and the operational environment.

- $\quad$ Supply support and spares: are not necessarily always available and need to be procured from international suppliers. Obsolescence applies here in some cases.

- $\quad$ Support and test equipment (S\&TE): in some instances, the support and test equipment has become obsolete before the system has.

- $\quad$ System's operational requirements: it is necessary to know the system's operational requirements so that the correct quantity and types of resource are allocated.

- $\quad$ Technical data and documentation: are not necessarily kept up to date with amendments. The manuals are not necessarily written in the maintainer's mother tongue, and might be in their second or third language.

- $\quad$ Training and training devices: the OEMs of systems such as radar, navigational aids, and satellite earth stations might publish the manuals in English. This is also not necessarily the technical staff's first language, making the repair of the system difficult.

\section{5}

\section{CONCLUSION}

In this paper the development of ILS in 'beyond designed life systems' was discussed. Logistics not only influences the world wide economy, but also the well-being of an organisation, in that logistics costs are merely one of the costs influencing an organisation. The terms 'ILS', 'ILSS', and 'logistics' originate from the military; however, today ILS is used in aerospace, radar, the petrochemical industry, navigational aids, modular nuclear reactors, and satellite earth stations.

Various definitions of ILS are available in the literature. These definitions differ, depending upon their authors' background and whether they are from a military, industrial, or engineering environment. An ILS consists of various elements: computer resources, configuration management, disposal, facilities, maintenance support, manpower and personnel, obsolescence, PHS\&T, RAM, supply support, S\&TE, system operational requirements, technical data and documentation, and training and training devices. Each of these elements needs to be managed individually and as part of an integrated whole.

Specific risks and challenges in a developing country were identified in this paper. The risks might be lower in other environments, in terms of the significance of their impact and the likelihood of occurrence. These risks need to be assessed, and proactive mitigation plans and strategies need to be developed.

By implementing an ILSS, a high-technology complex system can be maintained and supported throughout its intended and often its extended life cycle. Such expensive high-technology complex systems need to function as designed. When obsolescence and supportability issues affect a beyond-design-life system, these issues need to be proactively managed. The successful implementation of an ILSS enables an organisation to deliver services and products efficiently and effectively in a competitive environment.

\section{REFERENCES}

[1] Lambert, D.M., Stock, J.R. \& Ellram, L.M. 1998. Fundamentals of logistics management. Boston: Irwin/McGrawHill.

[2] Jones, J.V. 1998. Integrated logistics support handbook, $2^{\text {nd }}$ ed. New York: McGraw-Hill.

[3] 1974. The New Encyclopaedia Britannica Volume 11. Macropædia, $15^{\text {th }}$ ed. Edinburgh: Encyclopædia Britannica.

[4] Blanchard, B.S. 1992. Logistics engineering and management, $4^{\text {th }}$ ed. Englewood Cliffs, New Jersey: Prentice-Hall.

[5] Pagonis, W.G. with Cruikshank, J.L. 1992. Moving mountains: Lessons in leadership and logistics from the Gulf War. $1^{\text {st }}$ ed. Boston, Massachusetts: Harvard Business Review Press.

[6] McKinsey Quarterly. 1991. [Information unknown; cited in Pagonis, 1992]. 
[7] Lambert, K.R. 2008. The development of a framework for an integrated logistics support system within a high technology industry in a developing country. DBL thesis. University of South Africa.

[8] Hutchinson, N.E. 1987. An integrated approach to logistics management, $1^{\text {st }}$ ed. Englewood Cliffs, NJ: PrenticeHall.

[9] Quayle, M. 1993. Logistics: An integrated approach. Eastham, Wirral, Merseyside: Tudor Business Publishers.

[10] Lambert, D.M. \& Stock, J.R. 1993. Strategic logistics management. Homewood, IL: Richard D. Irwin (cited in Juga, 1996).

[11] Juga, J. 1996. Changing logistics organization. Turku, Finland: Turku School of Economics and Business Administration.

[12] Adler, L. 1967. Systems approach to marketing. Harvard Business Review, 45(3), pp. 105-118 (cited in Juga, 1996).

[13] Jones, J.V. 2006. Integrated logistics support handbook, $3^{\text {rd }}$ ed. New York: SOLE Logistics Press, McGraw-Hill.

[14] United States Department of Defense. 1988. MIL-STD-1368-A. Integrated logistic support program requirements. Washington, DC: Department of Defense.

[15] Army Regulation 700-127. 1999. Integrated logistics support. Washington, DC: Headquarters Department of the Army.

[16] United States Department of Defense. 1983. Directive 5000.39: Acquisition and management of integrated logistic support for systems and equipment. Washington, DC: Department of Defense (cited in Blanchard, 1992).

[17] Marshall, M.M. \& Lambert, K.R. 2007. Development of an integrated logistics support system (ILSS) in systems beyond designed life. Proceedings of the 2007 IEMS Conference, pp. 554-563, Cocoa Beach, Florida.

[18] Carpenter, J.L. 1967. Integrated logistics support. Hanover, MD: NASA Center for Aerospace Information (CASI).

[19] Finkelstein, W. \& Guertin, J.A.R. 1988. Integrated logistics support: The design engineering link, 1st ed. London: IFS Publications, UK and Springer-Verlag.

[20] Langford, J.W. 1995. Logistics: Principles and applications. New York: McGraw-Hill.

[21] ARINC. 2000. Program managers handbook: Common practices to mitigate the risk of obsolescence, Revision D. Annapolis, Maryland: Prepared for Defense Micro-electronics Activity (DMEA).

[22] Pingle, P. 2015. Selection of obsolescence resolution strategy based on a multi criteria decision model. Unpublished Master of Science thesis, lowa State University.

[23] Sandborn, P. 2013. Design for obsolescence risk management. Procedia CIRP, 11, pp. 15-22.

[24] Howard, M.A. 2002. Component obsolescence: It's not just for electronics anymore. Proceedings of the Aging Aircraft Conference, San Francisco, CA, 2002.

[25] Haub, F. 1997. Managing materiel shortages the USN Way. In International Defence review-extra, Vol. 2 , No. 009.

[26] Meyer, A., Pretorius, L. \& Pretorius, J.H.C. 2003. A management approach to component obsolescence in the military electronic support environment. SA Journal of Industrial Engineering, 14(2), pp. 121-136.

[27] Sherwin, D. 2000. A review of overall models for maintenance management. Journal of Quality in Maintenance Engineering, 6(3), pp. 138-164.

[28] Livingston, H. 2000. GEB1: Diminishing manufacturing sources and material shortages (DMSMS) management practices. [S.l.: s.n.]. Available from: http://www.dmea.osd.mil/docs/geb1_paper.pdf (Accessed 07 September 2017). 